\title{
Brain Television: A Research of Visual Effects for Early Years
}

\author{
Muhibuddin Fadhli \\ Muhammadiyah University Of Ponorogo \\ Corresponding e-mail: themadrock@gmail.com
}

\begin{abstract}
This study examined television program effects towards young children. Television has become an increasingly accepted entertainment washing tool in children's brain. Previous research has indicated that television program can be destructive if it is not used wisely. It is really hard to avoid television as a kid. People at home usually get into TV - children and parents. In some families, television is sometimes turned on even without anyone watch it. It is common for parents and caregivers to use TV as a substitute babysitter. Besides, many parents buy videos aiming at making their kids smart. But how does watching TV really affect children? This study explained the advantages and disadvantages of watching TV for early years.
\end{abstract}

Keywords: Television, children, early years

\section{INTRODUCTION}

Television (TV) is the most popular tool used to entertain people. People use TV to spend their leisure times, to educate their children, to entertain, and other activities that they can do with it. TV is an equipment to deliver information among people around the world. As parents, we know the advantages and disadvantages of watching television but unfortunately we cannot be around with our children all the time when they are watching TV even though TV channels provide categories of viewers aiming at giving consideration on how to watch TV wisely, particularly of children.

Nowadays, television is one of the most influential sources of media in any children's life. As parents, we are most likely on a constant battle with our children over the TV remote. What to watch, when to watch and how many to watch - are some topics that most parents have to think of. But as much as parents try and limit it, television does end up in playing a big role towards your children's growing up years. TV viewing among kids is at an eight-year high. On average, children ages 2-5 spend 32 hours a week in front of a TV-watching television, DVDs, DVR and videos, and using a game console. Kids ages 6-11 spend about 28 hours a week in front of the TV. The vast majority of this viewing (97\%) is of live TV (Patricia McDonough, n.d.)

The bad news is we cannot remove it. The good news is we can use it to our benefits. Limited and supervised screen time can be a positive experience for children. It can be beneficial if you are involved when your children are watching a show. Not only does television influence your children, it also takes them to places around the world and opens up a treasure chest of information. All you need to do as parents is to differentiate the good and bad.

$\mathrm{TV}$ rots the senses occurring in the head. It kills the imagination. It clogs and clutters up our mind. It makes a child so dull and blind. He can no longer understand a fantasy, a fairyland! His brain becomes so mild. His power of thinking rusts and freezes. An excerpt from Charlie and the Chocolate Factory (Dahl, n.d.). It means that television can be destructive and uneducated equipment, therefore, we have to move and change children's habit on watching television. 


\section{LITERATURE REVIEW}

\subsection{Visual Spatial Intelligence}

Central to spatial intelligence are the capacities to perceive the visual world accurately, to perform transformations and modifications upon one's initial perceptions, and to be able to re-create aspects of one's visual experience, even in the absence of relevant physical stimuli. One can be asked to produce forms or simply to manipulate those that have been provided. (Gardner, 1988)

These abilities are clearly not identical: an individual may be acute, say, in visual perception, while having little ability to draw, imagine, or transform an absent world. We have seen, in the preceding discussion, that spatial intelligence entails a number of loosely related capacities: the ability to recognize instances of the same element, the ability to transform or to recognize a transformation of one element into another, the capacity to conjure up mental imagery and then to transform that imagery, the capacity to produce a graphic likeness of spatial information, and the like. Conceivably, these operations are independent of one another and could develop or break down separately; and yet, just as rhythm and pitch work together in the area of music, so, too, the aforementioned capacities typically occur together in the spatial realm. Indeed, they operate as a family, and use of each operation may well reinforce use of the others.

\subsection{Visual Intelligence and Television}

A television is one of visual media that deliver information from sender to receiver, past research proves that visual media can stimulate the children's growth and development, moreover, visual media can give a contribution to children's understanding about 30\% (Dale, 1969)

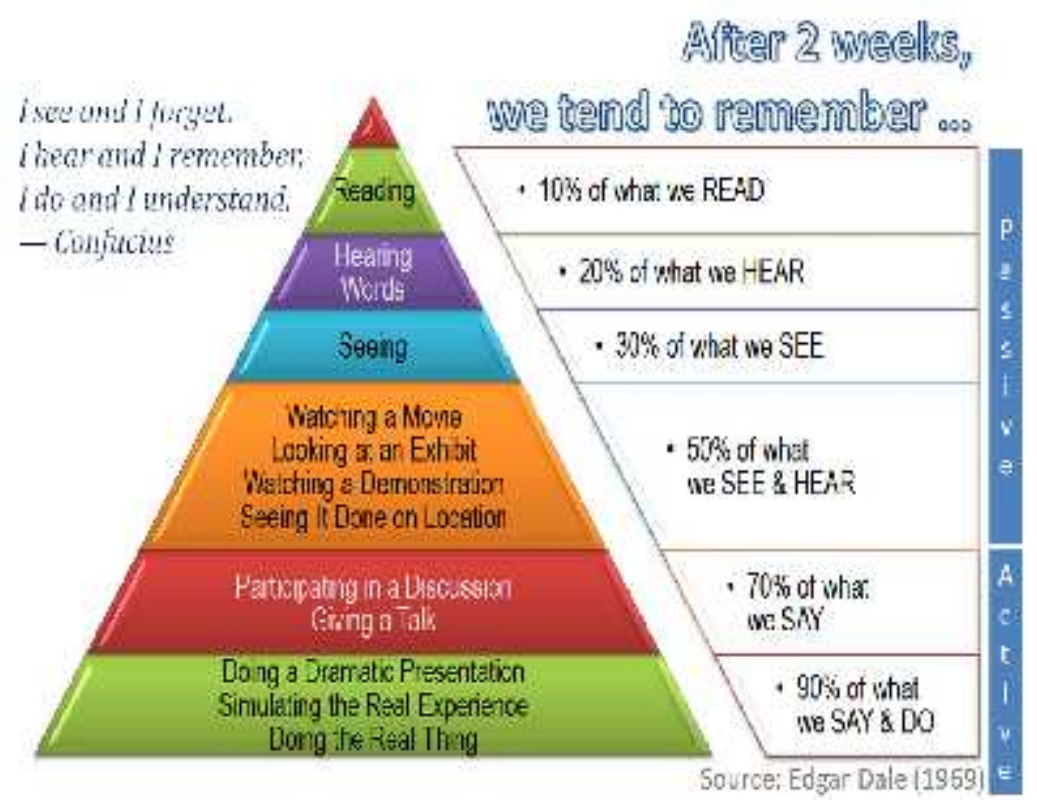

Figure 1. Dale's Cone of Experience

Also, we could see they can receive more information than another medium i.e. audio. A research proves an effectiveness of visual media, in a classroom which provides two visual media, one is a picture and a video is another. This research indicates that video is more effective to reinforce students' understanding than picture. (Fadhli, 2015)

Television is a part of visual media, we started using television as a commercial product in 1920. During this period, the use of television widely spread in the entire world, moreover, in the World
War II, the Germany used television to brainwash the society and used it as a tool of propaganda. The word 'television' is from Greek tele meaning far and visio meaning vision. Hence, television could be defined as the tool of long communication which uses visual media or vision.

The history of television in Indonesia was recorded in August 1962, the only television station was TVRI (Republic of Indonesia Television). Programs were presented in the form of actual news that happened at that time. The development of the 
television industry entered a period in 1990s where many television programs presented an interesting event and made people enjoy to sit in front of their screen.

Years by years the television industry entered a new era, many programs can be beneficial, yet, many programs are endangering our children, so, it is necessary for parents to accompany their children when they are watching television.

Indonesian government requires the commission of broadcaster firm to select TV programs. There are categories included in television programs, namely, adult viewers category, adolescent viewers and all ages category. In some countries, Television programs may be fictional (comedies and dramas),or nonfictional (documentary, news, and reality television). It may be topical (local newscast and some madefor-television movies), or historical (documentaries and fictional series). They could be primarily instructional or educational, or entertaining such as the case in situation comedy and game shows. As parents we must know what children need and we can select the appropriate programs for our kids and suit for their development.

The children are so close to television. We know that some children hardly sleep when they do not see their favorite programs, and we can see some children cry when their favorite programs cannot be shown. Unfortunately, the programs that they are addicted to contain adult materials, therefore the contents are not appropriate with their needs.

\section{RESEARCH METHODOLOGY}

This research is based on qualitative principles which the researcher as an instrument itself, in a qualitative study believes that the truth is dynamic and can be found only through the review of the people through their interaction with their social situation. The events that occur in a social situation is the main study of qualitative research.

In this article will discuss about the impacts caused when early childhood tend to enjoy television, and away from activities that stimulate the growth of physical or mental, need to do further study on how to find the best solution when children are addicted to television and how it effects the future.

This research was carried out independently, involving several objects of research in which the author is a research instrument itself, there are two children who were involved in this research, these two kids just addict to television and have a hobby to see the adult category like soap operas and programs that are not educate at all.

\subsection{Data Analysis and Findings}

In a description of a qualitative research, it needs a method to collect the relevant data. This study used interviews and observations. Observations were conducted with both parents and two children who were involved. Both like television, but there is a difference existed. On one hand, a child who only watches television on their parents' permission and on the other hand, a child who watches television on their own will and desire.

From the interviews result towards parents the following data were obtained (the interview was conducted in a different time and place):

Table 1. Results of parents interview

\begin{tabular}{l|l|l}
\hline \multicolumn{1}{c|}{ Questions } & \multicolumn{1}{|c|}{ Parent A } & \multicolumn{1}{c}{ Parent B } \\
\hline $\begin{array}{l}\text { Does your child } \\
\text { love to watch } \\
\text { television? }\end{array}$ & $\begin{array}{l}\text { Of course yes, } \\
\text { he loves } \\
\text { watching he does } \\
\text { television very } \\
\text { much }\end{array}$ & \\
\hline $\begin{array}{l}\text { How long does } \\
\text { your children } \\
\text { watch television } \\
\text { in one day? }\end{array}$ & $\begin{array}{l}\text { Umm, I think } \\
\text { about 4 to 5 } \\
\text { hours per day. }\end{array}$ & 3 hours a day. \\
\hline
\end{tabular}

Table 1. Cont.

\begin{tabular}{|c|c|c|}
\hline $\begin{array}{l}\text { What's the } \\
\text { favorite } \\
\text { program? }\end{array}$ & $\begin{array}{l}\text { Sometimes, they } \\
\text { watch cartoon } \\
\text { network, drama, } \\
\text { and music } \\
\text { programs. }\end{array}$ & $\begin{array}{l}\text { Cartoon } \\
\text { Network, } \\
\text { Drama }\end{array}$ \\
\hline $\begin{array}{l}\text { Do you } \\
\text { accompany } \\
\text { them when } \\
\text { they're } \\
\text { watching } \\
\text { television? }\end{array}$ & $\begin{array}{l}\text { Of course, I keep } \\
\text { an eye on them } \\
\text { and don't give } \\
\text { them permission } \\
\text { to switch on } \\
\text { television alone. }\end{array}$ & $\begin{array}{l}\text { Rarely, I } \\
\text { always give } \\
\text { them freedom } \\
\text { to watch } \\
\text { television, } \\
\text { sometimes he } \\
\text { gets mad } \\
\text { when I } \\
\text { accompany } \\
\text { him. }\end{array}$ \\
\hline $\begin{array}{lr}\text { Do } & \text { children } \\
\text { imitate } & \text { public }\end{array}$ & $\begin{array}{l}\text { Yes they do, } \\
\text { sometimes they }\end{array}$ & $\begin{array}{l}\text { Exactly, } \\
\text { they copy all }\end{array}$ \\
\hline
\end{tabular}




\begin{tabular}{l|lr|lr}
$\begin{array}{l}\text { figure's } \\
\text { behavior when } \\
\text { they are }\end{array}$ & $\begin{array}{l}\text { imitate the } \\
\text { sounds of }\end{array}$ & $\begin{array}{l}\text { of the } \\
\text { behavior. He } \\
\text { catching } \\
\text { television? }\end{array}$ & $\begin{array}{l}\text { always gets } \\
\text { characters, like } \\
\text { angry when I }\end{array}$ \\
& $\begin{array}{l}\text { laugh, angeBob's } \\
\text { patrick's } \\
\text { innocent. }\end{array}$ & $\begin{array}{l}\text { atempt to } \\
\text { remind that } \\
\text { what he does }\end{array}$ \\
& in \\
& inappropriate.
\end{tabular}

We are doing an interview to know how far the impact of television program to children's habits is, and also, in this research we collect the data from children who addicted to television. Here are some interviews.

Table 2. Result of Children Interview

\begin{tabular}{|c|c|c|}
\hline Questions & Child A & Child B \\
\hline $\begin{array}{l}\text { Halo, may I } \\
\text { have } \\
\text { question to } \\
\text { you, do you } \\
\text { love watching } \\
\text { television? }\end{array}$ & $\begin{array}{l}\text { Yes, I do, I } \\
\text { watch } \\
\text { television } \\
\text { everyday }\end{array}$ & $\begin{array}{l}\text { Yes, I always } \\
\text { watching } \\
\text { television, } \\
\text { especially, } \\
\text { before sleeping. }\end{array}$ \\
\hline $\begin{array}{l}\text { What is your } \\
\text { favorite } \\
\text { programmer? }\end{array}$ & Cartoon & $\begin{array}{l}\text { I prefer to } \\
\text { watch drama. }\end{array}$ \\
\hline $\begin{array}{l}\text { When you are } \\
\text { watching, do } \\
\text { you want to } \\
\text { accompany? } \\
\text { And who want } \\
\text { to accompany } \\
\text { you? }\end{array}$ & $\begin{array}{l}\text { Yep, } \\
\text { sometimes } \\
\text { my mother sit } \\
\text { next to me. }\end{array}$ & $\begin{array}{l}\text { I prefer to } \\
\text { watch alone, } \\
\text { and nobody is } \\
\text { bothering me. }\end{array}$ \\
\hline
\end{tabular}

Table 2. Cont.

\begin{tabular}{l|l|l}
\hline $\begin{array}{l}\text { What is your } \\
\text { favorite } \\
\text { character? }\end{array}$ & $\begin{array}{l}\text { I love } \\
\text { SpongeBob }\end{array}$ & $\begin{array}{l}\text { Hmm, I'm not } \\
\text { sure his name, } \\
\text { but he is a } \\
\text { handsome man } \\
\text { in the serial } \\
\text { "anak jalanan" }\end{array}$ \\
\hline $\begin{array}{l}\text { Oke kids, this } \\
\text { is the last } \\
\text { question from } \\
\text { me, do you } \\
\text { like to copy to } \\
\text { your favorite } \\
\text { character. }\end{array}$ & $\begin{array}{l}\text { Yes, } \\
\text { sometimes I I } \\
\text { laugh like a aa... }\end{array}$ & $\begin{array}{l}\text { Yes, I usually } \\
\text { copy the motor } \\
\text { sound and the } \\
\text { cool outfit that is } \\
\text { awesome. }\end{array}$ \\
\hline
\end{tabular}

In the interviews, we can get the information that children in Indonesia tend to love watching television. The average duration to watch television is about 3-4 hours, so that, the long duration they spend could give a bad news to their development, this is a serious problem. We know that television is strong enough to take a place for children development. However, we can facilitate them with useful things introducing them with more exciting and fun activities, like playing with their friends or other fun activities.

The findings show that parents have hilarious roles that they have to be a good model to their children. Also, the observation indicates that parents take a place to establish the children habits. The data show that there are parents having a big attention to their children i.e they always sit next to their children while watching television. However, we can also see that parents don't care and let their children watch television alone. We can see the differences between A Characters and B Characters. A tend to be obedient and very kind when we are doing interviews. He always smiles and answers all questions. Yet, B is not really indigenous. He is not really like other kids that he tends to get angry, spontaneous, not really confident about himself, and does not really care about surroundings.

\section{CONCLUSIONS}

The brainwasher a.k.a television can be very beneficial in some cases and could be a medium to send a good information about good things. Nevertheless, this tool could be very destructive to children. The findings show the harm of television so as parents we have to make this tool could be a good friend for our children. Here are some consideration when using television.

a. Parents must accompany their children when they are watching television.

b. Arrange a schedule, and always be there when they are watching.

c. Pay attention of viewer's category.

d. Discuss about the programs.

\section{REFERENCES}

Dahl, R. (n.d.). Dahl, Roald - Charlie and the Chocolate Factory.

Dale, E. (1969). Audiovisual Methods in Teaching. Third Edition. NY : Dryden Press. https://doi.org/10.1108/00400910910987273

Fadhli, M. (2015). PENGEMBANGAN MEDIA PEMBELAJARAN BERBASIS VIDEO KELAS IV SEKOLAH DASAR. Jurnal 
Dimensi Pendidikan Dan Pembelajaran, 3(1).

Gardner, H. (1988). Frames of mind. Psychoanalytic process research strategies. https://doi.org/10.2307/3324261

Patricia McDonough. (n.d.). TV VIEWING AMONG KIDS AT AN EIGHT-YEAR HIGH Retrieved from http://www.nielsen.com/us/en/insights/news/20 09/tv-viewing-among-kids-at-an-eight-yearhigh.html 